\title{
Analysis of the Postgraduate Theses Completed in the Field of Teacher Education Programs
}

\section{Research Article}

\section{Serap Nur DUMAN ${ }^{1}$}

${ }^{1}$ Asst. Prof.,Kırıkkale University, Faculty of Education, Department of Curriculum and Instruction, Kırıkkale, Turkey, ORCID: 0000-0002-45352144

To cite this article: Duman, S. N. (2021). Analysis of the postgraduate theses completed in the field of teacher education programs, International Online Journal of Educational Sciences, 13(4), 1107-1125.

\begin{tabular}{ll} 
ARTICLE INFO & ABSTRACT \\
\hline Article History: & $\begin{array}{l}\text { Although there are many variables in teacher training process, the most important components are } \\
\text { teachers, prospective teachers, teacher educators and teacher education programs. Many articles and } \\
\text { Received: 25.01.2021 }\end{array}$ \\
thesis studies are done on teacher education programs among these components. This study aims to \\
analyze the postgraduate theses completed on the subject of teacher education programs. Descriptive \\
research design was used in the study. 310 postgraduate theses on teacher education programs which \\
were completed between 1988 and 2020 and are open access on the database of National Thesis \\
Center were included in the study. In the analysis of the postgraduate theses determined, document \\
analysis was used. The distribution of the theses according to universities, institutes, departments, \\
subjects, research methods, research designs, samples, and data collection tools was examined and \\
the relevant findings were presented in tables. Based on the findings, it was determined that the \\
theses on teacher education programs were generally completed in METU, institutes of educational \\
sciences and department of educational sciences. It was found that the subject mostly studied was \\
teacher qualifications or prospective teacher qualifications. Qualitative and quantitative research \\
methods were used equally in the theses. In addition, it was determined that survey model was used \\
at the most as research design and prospective teachers were included mostly as sample in the theses. \\
Interview forms were mostly preferred as data collection tool in the theses.
\end{tabular}

(C) 2021 IOJES. All rights reserved

Keywords:

Teacher education program, Teacher education, Postgraduate, Theses.

\section{Introduction}

Change is inevitable in many areas ranging from science to art, technology, and education. The period of change through which individuals, societies and the world have gone for a while now requires that basic systems such as health, economics, politics, and education should constantly improve themselves. This change

${ }^{1}$ Corresponding author's address: Kırıkkale Üniversitesi

Telephone: +905073076945

e-mail: serapnurcanoglu@gmail.com

DOI: https://doi.org/10.15345/iojes.2021.04.011 
in the education system takes place on the teacher, student and curriculum triangle (Yilman, 2006, p. 21). Correspondingly, the regulations also made on our education system are related to teacher education or curricula. It was seen that regulations on the structural context of teacher education were made especially after teacher training was placed under the responsibility of universities on the $20^{\text {th }}$ July of 1982 (Yüksel, 2011, p. 53). One of these regulations was initiated in 1997 and significant decisions on restructuring teacher education programs were made (CoHE, 1998). However, the negative evaluations on the changes made it necessary to work on teacher education programs again in 2006. A more flexible approach to the curriculum was adopted in the scope of the new teacher education programs started to be implemented in the academic year 2006-2007. As a result, faculties were authorized to determine the courses at the rate of approximately $25 \%$ of the total credits required in a curriculum. With this restructuring, it was aimed to adopt the understanding of training teachers who have the ability of problem solving and teach how to learn (CoHE, 2007). Teacher education programs were maintained in the current state for about twelve years to train teachers. In 2008, teacher education programs were rearranged and it was aimed to develop a core curriculum in teacher education programs by determining the rates of professional teaching knowledge, general culture and field training courses included in the curriculum (CoHE, 2018). Nearly two years after this arrangement, on August 18, 2020, the Council of Higher Education (CoHE) announced that it authorized the universities. Accordingly, it was stated that higher education institutions were responsible for preparing their own teacher education programs by taking into account the Turkish Qualifications Framework and Teaching Profession General Qualifications (CoHE, 2020). When all these reforms are considered, the importance of teacher education programs for training qualified teachers and in the field of teacher education reveals. One of the important issues is how to strengthen teacher education programs in order to ensure the future teachers gain more experience in the aspects of knowledge, skill and practice (Darling-Hammond, 2000; 2006; Yildırım, 2013). The way to strengthen teacher education is through strengthening teacher education programs. For this reason, there is a need to examine the researches on teacher education programs in detail. Among these researches, especially postgraduate theses have an important place in terms of presenting comprehensive findings. The views of many teachers, students and academics can be reached with master's and doctoral theses on teacher education programs. At the same time, it is necessary to evaluate the studies conducted on teacher education programs together in order to evaluate the effects of the program changes made in 1998, 2006 and 2018 on pre-service teachers and teachers. A comprehensive study that evaluates research on teacher education programs together has not been found yet. For this reason, it is seen that there is a need for studies that address the studies on teacher education programs and reveal together what methods and how these studies reach their findings. In this context, the main objective of this research is to evaluate the studies conducted for teacher education programs together and to present a general perspective regarding these studies. In order to achieve this objective, 310 postgraduate theses that were done on teacher education programs (TEPs) and are open to access on the National Thesis Center database were analyzed. The distribution of the postgraduate theses done in the field of TEPs according to universities, institutes, departments, subjects, research methods, research designs, samples, and data collection tools was examined and interpreted in detail.

\section{Method}

\section{Research Model}

Descriptive research design was used in this study since the aim is to identify the postgraduate theses completed in the subject of teacher education programs (TEPs) that still exist today elaborately (Büyüköztürk, Kılıç Çakmak, Akgün, Karadeniz \& Demirel, 2012, p. 22; Sönmez \& Alacapınar, 2013, p. 48). The research also shows the characteristics of qualitative research since document analysis was used in the analysis of the postgraduate theses on teacher education programs in the scope of this study. Qualitative research is defined 
as a research method that uses qualitative data collection tools such as observation, interview, and document analysis, and reveals events and phenomena realistically and holistically (Yıldırım \& Şimşek, 2013, p. 45).

\section{Sample}

The research sample consisted of a total of 310 master's theses and dissertations on teacher education programs that were completed between 1988 and 2020 and are open to access on the National Thesis Center database. For this reason, sampling was not carried out and the whole population was included in the study. Key words used in the selection of theses in the research: faculty of education undergraduate programs, preservice teacher improvement programs, faculty of education programs, teacher education programs, preservice teacher education programs and teacher training programs. Searching with these keywords revealed that the first thesis was made in 1988. For this reason, theses that were open to access between 1988-2020 formed the sample of the research. The distribution of the postgraduate theses in the study according to their levels was presented in Table 1.

Table 1. Distribution of theses according to levels

\begin{tabular}{|c|c|c|c|}
\hline \multirow{2}{*}{ Years } & \multicolumn{3}{|c|}{ Thesis Level } \\
\hline & Master's Thesis & Dissertation & Total \\
\hline 1988 & & 1 & 1 \\
\hline 1991 & & 1 & 1 \\
\hline 1994 & 3 & & 3 \\
\hline 1996 & & 1 & 1 \\
\hline 1999 & 1 & & 1 \\
\hline 2000 & & 1 & 1 \\
\hline 2001 & 1 & 1 & 2 \\
\hline 2002 & & 1 & 1 \\
\hline 2003 & 2 & 1 & 3 \\
\hline 2004 & 5 & 3 & 8 \\
\hline 2005 & 2 & 1 & 3 \\
\hline 2006 & 7 & & 7 \\
\hline 2007 & 2 & 4 & 6 \\
\hline 2008 & 11 & 4 & 15 \\
\hline 2009 & 4 & 3 & 7 \\
\hline 2010 & 9 & 4 & 13 \\
\hline 2011 & 5 & 3 & 8 \\
\hline 2012 & 13 & 4 & 17 \\
\hline 2013 & 3 & 7 & 10 \\
\hline 2014 & 11 & 5 & 16 \\
\hline 2015 & 15 & 10 & 25 \\
\hline 2016 & 13 & 21 & 34 \\
\hline 2017 & 17 & 19 & 36 \\
\hline 2018 & 12 & 16 & 28 \\
\hline 2019 & 37 & 14 & 51 \\
\hline 2020 & 7 & 5 & 12 \\
\hline Total & 180 & 130 & 310 \\
\hline
\end{tabular}

Table 1 shows that 180 master's theses and 130 dissertations were included in the study. When the distribution of the theses according to their levels was examined, it was found that the most theses were completed in 2019. Only one thesis was done in 1988, 1991, 1996, 1999, 2000 and 2002.

The distribution of the postgraduate theses in the study according to gender was shown in Table 2. 
Table 2. Distribution of theses according to gender

\begin{tabular}{|c|c|c|c|}
\hline \multirow{2}{*}{ Years } & \multicolumn{3}{|c|}{ Gender } \\
\hline & Female & Male & Total \\
\hline 1988 & & 1 & 1 \\
\hline 1991 & & 1 & 1 \\
\hline 1994 & 2 & 1 & 3 \\
\hline 1996 & 1 & & 1 \\
\hline 1999 & & 1 & 1 \\
\hline 2000 & 1 & & 1 \\
\hline 2001 & & 2 & 2 \\
\hline 2002 & & 1 & 1 \\
\hline 2003 & 1 & 2 & 3 \\
\hline 2004 & 4 & 4 & 8 \\
\hline 2005 & 3 & & 3 \\
\hline 2006 & 5 & 2 & 7 \\
\hline 2007 & 4 & 2 & 6 \\
\hline 2008 & 8 & 7 & 15 \\
\hline 2009 & 5 & 2 & 7 \\
\hline 2010 & 8 & 5 & 13 \\
\hline 2011 & 5 & 3 & 8 \\
\hline 2012 & 10 & 7 & 17 \\
\hline 2013 & 6 & 4 & 10 \\
\hline 2014 & 8 & 8 & 16 \\
\hline 2015 & 12 & 13 & 25 \\
\hline 2016 & 20 & 14 & 34 \\
\hline 2017 & 19 & 17 & 36 \\
\hline 2018 & 18 & 10 & 28 \\
\hline 2019 & 39 & 12 & 51 \\
\hline 2020 & 9 & 3 & 12 \\
\hline Total & 188 & 122 & 310 \\
\hline
\end{tabular}

Table 2 shows that 188 of the postgraduate theses in the study were completed by female researchers and 122 postgraduate theses were completed by male researchers.

\section{Data Collection Tool}

The table of specifications that was prepared by the researcher was used in order to collect the postgraduate theses as the data in the study. The prepared table of specifications was two-dimensional. In one dimension of the table, the keywords used while searching for theses were included and the year when the thesis was completed was given in the other dimension. The keywords used in the search for theses were six in total: "faculty of education undergraduate programs" (5 theses), "pre-service teacher improvement programs" (3 theses), "faculty of education programs" (7 theses), "teacher education programs" (70 theses), "pre-service teacher education programs" (2 theses), and "teacher training programs" (241 theses). A total of 328 theses were reached by using these keywords. Since 18 of these studies were duplicated in the search categories, it gives the final sample of 310 theses to include in this study. All of the searches on the National Thesis Center database that were made via the keywords were carried out in "all" option. With this option, the keywords were searched in all fields from the title of thesis to the author, supervisor, subject, index, and abstract.

\section{Data Collection}


The postgraduate theses included in the study were collected by the researcher through direct access from the official website of the National Thesis Center. Theses accessed with the keywords used in the data collection process were filed and saved separately by the researcher without any intervention. In order to check the accuracy of the theses and to ensure the reliability of the data collection process, an expert in educational sciences, not included in the study, was asked opinion. The table of specifications prepared with the keywords used in the search for thesis was presented to the field expert and it was requested to carry out a new search on the National Thesis Center database. The theses accessed by the expert were compared and the postgraduate theses included in the research were confirmed (Creswell, 2017, p. 289).

\section{Data Analysis}

Document analysis was used in order to analyze the postgraduate theses done on teacher education programs that were included in the study. The process of document analysis is realized in five steps as accessing the documents, checking the authenticity of the documents, consideration about the documents, analyzing the data and using the data (Forster, 1995 as cited in Yıldırım \& Şimşek, 2013, p. 223).

The steps followed accordingly in the research are listed below.

- Accessing the documents: The theses were directly accessed from the official website of the National Thesis Center. In order to access the theses, search was carried out with the keywords determined and 310 open access theses were included in the research.

- Checking the authenticity: A separate search was carried out by an expert in educational sciences who was not included in the study with the same keywords at a different time. Theses accessed by the field expert and the researcher were compared and the authenticity of theses was checked.

- Consideration about the documents: Theses were searched by the researcher by using different keywords and the theses for each year were separately saved. The relevance of the keywords used in the thesis search in this process to the objective of the research was checked by two experts in assessment and evaluation. In addition, two experts in assessment and evaluation were asked opinion for the content validity regarding the table of specifications used in the research.

- Analyzing the data: Descriptive analysis was used in the analysis of theses. While conducting descriptive analysis, firstly, the theses were examined and the themes were determined. The determined themes were university, institute, department, subject, research method, research design, sample, and data collection tool. Prior to the analysis of theses, two experts in educational sciences and one expert in assessment and evaluation were asked for opinion about the relevance of these themes that would be used in descriptive analysis to the research.

- Using the data: Findings obtained as a result of descriptive analysis were presented in tables and interpreted.

\section{Validity and Reliability}

Expert opinion was sought in each stage of the research process in order to ensure the validity and reliability of the study. Experts in educational sciences and in assessment and evaluation were asked for opinion while preparing the table of specifications, using keywords, checking authenticity of theses, and analyzing theses. In addition, each stage of the research was reported in detail for both the readers and researchers (Yıldırım \& Şimşek, 2013, pp. 291-296). In the process of ensuring the reliability of the research; the purpose of the research was clearly stated, the documents used in the research were checked, and it was checked by the field expert that the findings showed a meaningful parallelism with the documents. In order to ensure the validity of this qualitative research, how the documents constituting the sample of the research were determined, how the documents were accessed and which data collection tool was used in the documents were reported in detail (Miles \& Huberman, 2015, pp. 278-279). 


\section{Findings}

Findings obtained in the research were presented in tables and interpreted in this section.

\section{Distribution of Theses According to Universities}

The distribution of the postgraduate theses completed in the field of teacher education programs (TEPs) according to universities was presented in Table 3.

Table 3. Distribution of theses according to universities

\begin{tabular}{|c|c|c|c|c|c|c|c|c|c|c|c|c|}
\hline \multirow[b]{2}{*}{ Years } & \multicolumn{12}{|c|}{ Universities } \\
\hline & 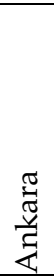 & $\stackrel{?}{e}$ & 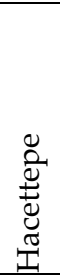 & $\begin{array}{l}\bar{N} \\
\mathbb{J}\end{array}$ & 苛 & 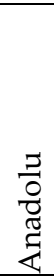 & $\begin{array}{l}\tilde{\sigma} \\
\stackrel{0}{0} \\
\stackrel{\Xi}{J} \\
\tilde{J}\end{array}$ & $\begin{array}{l}\vec{\Xi} \\
\overrightarrow{0} \\
\text { ज्ञ } \\
\text { ज्ञ }\end{array}$ & 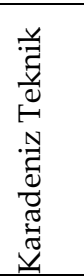 & 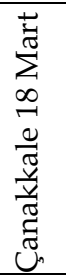 & 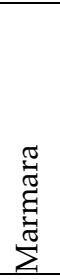 & $\frac{\grave{\Xi}}{\grave{0}}$ \\
\hline 1988 & 1 & & & & & & & & & & & \\
\hline 1991 & & 1 & & & & & & & & & & \\
\hline 1994 & 2 & & 1 & & & & & & & & & \\
\hline 1996 & & & & & 1 & & & & & & & \\
\hline 1999 & & & & & 1 & & & & & & & \\
\hline 2000 & & 1 & & & & & & & & & & \\
\hline 2001 & 1 & & & & & & & & & & & 1 \\
\hline 2002 & 1 & & & & & & & & & & & \\
\hline 2003 & & 2 & & & & & & & & & & 1 \\
\hline 2004 & & 1 & & 1 & & 2 & 1 & & & & & 3 \\
\hline 2005 & & & 1 & & & 1 & & & & & & 1 \\
\hline 2006 & & & & 1 & & 1 & & 1 & & & & 4 \\
\hline 2007 & & & & & & 2 & 1 & & 1 & & & 2 \\
\hline 2008 & 2 & 2 & & 2 & 1 & 1 & & & & 1 & 2 & 4 \\
\hline 2009 & 1 & 1 & 2 & & & & 1 & & & & & 2 \\
\hline 2010 & 2 & 1 & & 1 & & & & 2 & 1 & & 1 & 5 \\
\hline 2011 & 1 & 1 & & 1 & & & & & 2 & 1 & & 2 \\
\hline 2012 & & 6 & & & & & & & & & & 11 \\
\hline 2013 & 1 & 3 & & & 1 & & & 2 & & 1 & & 2 \\
\hline 2014 & & 2 & 2 & 2 & 2 & 1 & 1 & & 2 & & 1 & 3 \\
\hline 2015 & 2 & 1 & 1 & 2 & 1 & & 1 & & 2 & & 2 & 13 \\
\hline 2016 & 2 & 8 & 2 & 4 & 3 & & & & 1 & 4 & & 10 \\
\hline 2017 & 4 & 2 & 4 & 5 & & 1 & 2 & 2 & & & 1 & 15 \\
\hline 2018 & 1 & 4 & 2 & 3 & 1 & 2 & & 1 & & & 1 & 13 \\
\hline 2019 & & 3 & 7 & 7 & 1 & 3 & 1 & & & 2 & 1 & 26 \\
\hline 2020 & & 1 & 1 & 1 & & & 1 & & 1 & & & 7 \\
\hline Total & 21 & 40 & 23 & 30 & 12 & 14 & 9 & 8 & 10 & 9 & 9 & 125 \\
\hline
\end{tabular}

While preparing Table 3, universities with 8 or more postgraduate theses were listed with their names in the table. Universities with less than 8 theses were given in the 'other' category of the table. The reason for this is that there are many universities that produce thesis in the range of 1-7. Since it would be difficult to show all universities on the table, the other category was prepared. It was determined that the master's theses and dissertations on teacher education programs were mostly studied in METU, Gazi, Hacettepe, and Ankara universities, respectively. In addition, Anadolu, Fırat, Karadeniz Teknik, Çukurova, Çanakkale 18 Mart, 
Marmara, and Istanbul universities also included postgraduate thesis studies in their academic programs for teacher education. Universities included in the other category were, respectively, Balıkesir, Dicle, and Yeditepe universities (6 theses), Bursa Uludağ, Yıldız Teknik, Erciyes, and Mersin universities (5 theses), Dokuz Eylül, Boğaziçi, Pamukkale, Sakarya, Inönü, and Ege universities (4 theses), Dumlupınar, Bolu Abant Izzet Baysal, Atatürk, Ihsan Doğramacı Bilkent, Eskişehir Osmangazi, Bahçeşehir, Niğde, and Kırıkkale universities (3 theses), Aydın Adnan Menderes, Necmettin Erbakan, Kahramanmaraş Sütçü Imam, Cumhuriyet, Kastamonu, Akdeniz, Muğla Sıtkı Koçman, Çağ, Van 100. Yıl, Mehmet Akif Ersoy, and Zonguldak Bülent Ecevit universities (2 theses), and Selçuk, Celal Bayar, Düzce, Ufuk, Sinop, 19 Mayıs, Istanbul Aydın, Recep Tayyip Erdoğan, Kafkas, Mevlana, Fatih, Zirve, Maltepe, Afyon Kocatepe, Gaziantep, Trakya, and Mustafa Kemal universities (1 thesis).

\section{Distribution of Theses According to Institutes}

The distribution of the postgraduate theses completed in the field of teacher education programs (TEPs) according to institutes was presented in Table 4.

Table 4. Distribution of theses according to institutes

\begin{tabular}{|c|c|c|c|c|c|c|c|}
\hline \multirow[b]{2}{*}{ Years } & \multicolumn{7}{|c|}{ Institutes } \\
\hline & $\begin{array}{c}\text { Educational } \\
\text { Sciences }\end{array}$ & $\begin{array}{c}\text { Social } \\
\text { Sciences }\end{array}$ & Sciences & $\begin{array}{c}\text { Health } \\
\text { Sciences }\end{array}$ & $\begin{array}{l}\text { Ataturk's Principles } \\
\text { and History of } \\
\text { Turkish Revolution }\end{array}$ & $\begin{array}{l}\text { Forensic } \\
\text { Sciences }\end{array}$ & $\begin{array}{c}\text { Postgraduate } \\
\text { Education }\end{array}$ \\
\hline 1988 & & 1 & & & & & \\
\hline 1991 & & 1 & & & & & \\
\hline 1994 & & 3 & & & & & \\
\hline 1996 & & 1 & & & & & \\
\hline 1999 & & 1 & & & & & \\
\hline 2000 & & 1 & & & & & \\
\hline 2001 & 1 & 1 & & & & & \\
\hline 2002 & & 1 & & & & & \\
\hline 2003 & & 2 & 1 & & & & \\
\hline 2004 & 3 & 5 & & & & & \\
\hline 2005 & 1 & 2 & & & & & \\
\hline 2006 & 2 & 5 & & & & & \\
\hline 2007 & 1 & 2 & 3 & & & & \\
\hline 2008 & 6 & 9 & & & & & \\
\hline 2009 & 1 & 5 & 1 & & & & \\
\hline 2010 & 4 & 6 & 3 & & & & \\
\hline 2011 & 3 & 5 & & & & & \\
\hline 2012 & 6 & 9 & 2 & & & & \\
\hline 2013 & 3 & 7 & & & & & \\
\hline 2014 & 12 & 3 & 1 & & & & \\
\hline 2015 & 16 & 6 & 2 & & 1 & & \\
\hline 2016 & 24 & 9 & 1 & & & & \\
\hline 2017 & 28 & 5 & 2 & & & 1 & \\
\hline 2018 & 15 & 10 & 1 & 1 & & & 1 \\
\hline 2019 & 34 & 12 & 3 & 2 & & & \\
\hline 2020 & 4 & 8 & & & & & \\
\hline Total & 164 & 120 & 20 & 3 & 1 & 1 & 1 \\
\hline
\end{tabular}

Table 4 shows that the postgraduate theses on the TEPs were generally done in the institutes of educational sciences and social sciences. In addition, the institutes of science also included teacher education programs. The institutes that produced the least number of theses in the field of TEPs were health sciences, 
Ataturk's principles and history of Turkish revolution, forensic sciences, and postgraduate education institutes. Since the departments and divisions in the faculties of education that implement teacher education programs and train teachers were mostly affiliated to the institutes of educational sciences and to the institutes of social sciences in the universities in which the institute of educational sciences did not exist, it was considered that the number of thesis was high in these two institutes.

\section{Distribution of Theses According to Departments}

The distribution of the postgraduate theses completed in the field of TEPs according to departments was presented in Table 5.

Table 5. Distribution of theses according to departments

\section{Departments}

\begin{tabular}{|c|c|c|c|c|c|c|c|c|c|c|c|}
\hline Years & $\bar{U}$ & 囲 & 罜 & 罠 & $\begin{array}{l}\vec{P} \\
\stackrel{\vec{I}}{\vec{I}}\end{array}$ & 竞 & 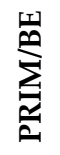 & 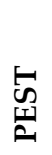 & $\underset{U}{\mathcal{H}}$ & $\sum_{\substack{\infty \\
\infty}}$ & $\begin{array}{l}\ddot{\Xi} \\
\stackrel{\Xi}{0}\end{array}$ \\
\hline 1988 & 1 & & & & & & & & & & \\
\hline 1991 & & 1 & & & & & & & & & \\
\hline 1994 & 3 & & & & & & & & & & \\
\hline 1996 & & 1 & & & & & & & & & \\
\hline 1999 & & 1 & & & & & & & & & \\
\hline 2000 & & 1 & & & & & & & & & \\
\hline 2001 & 1 & & & & & & & & & & 1 \\
\hline 2002 & & & & & & & & & & & 1 \\
\hline 2003 & & 1 & & & & & & & 1 & & 1 \\
\hline 2004 & & 3 & & & 2 & 1 & 1 & 1 & & & \\
\hline 2005 & & 1 & & 1 & 1 & & & & & & \\
\hline 2006 & 1 & 3 & 1 & & 1 & & 1 & & & & \\
\hline 2007 & 1 & & & & 1 & & 1 & & & 1 & 2 \\
\hline 2008 & 1 & 4 & 1 & 1 & & & 2 & 1 & 1 & 1 & 3 \\
\hline 2009 & 1 & 3 & & & 1 & & & & & 1 & 1 \\
\hline 2010 & 2 & 3 & & 2 & 1 & & & 1 & & 2 & 2 \\
\hline 2011 & 1 & & & & & & 2 & & 1 & 1 & 3 \\
\hline 2012 & 3 & 4 & & 1 & 2 & & 3 & & 1 & 1 & 2 \\
\hline 2013 & 1 & 4 & & 1 & & & & & 1 & & 3 \\
\hline 2014 & 2 & 1 & & 2 & 4 & & 3 & & 1 & 3 & \\
\hline 2015 & & 2 & 2 & 3 & 1 & & 4 & 1 & 1 & 2 & 9 \\
\hline 2016 & 2 & 8 & 2 & & 7 & 2 & 7 & 1 & 1 & 1 & 3 \\
\hline 2017 & 5 & 10 & 1 & 4 & 5 & 2 & 3 & & & 2 & 4 \\
\hline 2018 & 4 & 5 & & 4 & 2 & & 7 & 1 & & 2 & 3 \\
\hline 2019 & 6 & 13 & 2 & 5 & 4 & 2 & 7 & 3 & & 3 & 6 \\
\hline 2020 & 2 & 3 & & 3 & 3 & 1 & & & & & \\
\hline Total & 37 & 72 & 9 & 27 & 35 & 8 & 41 & 9 & 8 & 20 & 44 \\
\hline
\end{tabular}

(CI: Curriculum and Instruction, ES: Educational Science, EDAS: Educational Administration and Supervision, FLE: Foreign Language Education, ELT: English Language Teaching, ELI: English Language Instruction, PE: Private Education, PRIM: Primary, BE: Basic Education, PEST: Physical Education and Sports Teaching, CEIT: Computer Education and Instructional Technology, SSMT: Secondary Science and Mathematics Teaching.)

While preparing Table 5, departments with 8 or more postgraduate theses were listed with their names in the table. Departments with less than 8 theses were given in the 'other' category of the table. Departments in which the master's theses and dissertations on teacher education programs were mostly done were, 
respectively, Educational Sciences, Primary/Basic Education, Curriculum and Instruction, English Language Teaching/English Language Instruction, Foreign Language Education, and Secondary Science and Mathematics Teaching Department. In addition, it was determined that teacher education programs were also studied in the Departments of Educational Administration and Supervision, Physical Education and Sports Teaching, Private Education, and Computer Education and Instructional Technology. Departments included in the other category were, respectively, Fine Arts Education (6 theses), Primary Science and Mathematics Teaching (5 theses), Philosophy and Religious Sciences (4 theses), Secondary Social Studies Education and Preschool Education (3 theses), Classroom Education, Linguistics, and Cultural Foundations of Education (2 theses), Turkish Language Education and Teaching, Distance Education, Chemistry, Psychological Services in Education, Eastern Languages and Literature, Primary Science Teaching, Assessment and Evaluation, Music Education, Picture-Job Training, Political Science and Public Administration, Instructional Design and Evaluation, Environmental Sciences, Social Sciences, Educational Technology, Physics, Ataturk's Principles and History of Turkish Revolution, Primary Mathematics Teaching, and Turkish and Social Sciences Education Department (1 thesis).

The distribution of the postgraduate theses on the TEPs according to the institutes was found to be closely related to the distribution of theses according to the departments. The finding that the theses were generally done in the institutes of educational sciences and institutes of social sciences was consistent with the finding that the theses were mostly done in the departments of Educational Sciences, Primary/Basic Education, Curriculum and Instruction, English Language Teaching/English Language Instruction, Foreign Language Education, and Secondary Science and Mathematics Teaching. Based on this, it can be stated that teacher education programs was a research subject mainly related to the field of educational sciences.

\section{Distribution of Theses According to Subjects}

The distribution of the postgraduate theses completed in the field of TEPs according to subjects was presented in Table 6.

Table 6. Distribution of theses according to subjects

Subjects

\begin{tabular}{|c|c|c|c|c|c|c|c|c|c|c|c|c|c|c|c|}
\hline Years & $\stackrel{\omega}{H}$ & $\vec{\omega}$ & 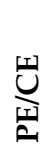 & 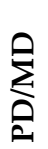 & $\underset{\psi}{U}$ & $\sum_{\in}^{U}$ & 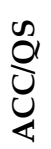 & 兒 & ثี & U্টে & 㭊 & $\stackrel{\varphi}{E}$ & 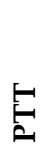 & $\stackrel{\mathscr{\omega}}{\vec{\omega}}$ & 旨 \\
\hline 1988 & 1 & & & & & & & & & & & & & & \\
\hline 1991 & & 1 & & & & & & & & & & & & & \\
\hline 1994 & & & 1 & & 1 & & & 1 & & & & & & & \\
\hline 1996 & & & 1 & & & & & & & & & & & & \\
\hline 1999 & & & 1 & & & & & & & & & & & & \\
\hline 2000 & & & & & 1 & & & & & & & & & & \\
\hline 2001 & & & 1 & & & & 1 & & & & & & & & \\
\hline 2002 & & & & & & 1 & & & & & & & & & \\
\hline 2003 & & & 1 & & & & & 2 & & & & & & & \\
\hline 2004 & & & 3 & 1 & & 1 & & & 1 & & & & 1 & & 1 \\
\hline 2005 & & & 1 & & & & 1 & 1 & & & & & & & \\
\hline 2006 & & & 2 & & & 2 & & 1 & & 1 & & 1 & & & \\
\hline 2007 & & & 1 & & & 3 & & 1 & & & & 1 & & & \\
\hline 2008 & 3 & & & & & 4 & 1 & 3 & 3 & & & 1 & & & \\
\hline 2009 & & & 2 & & 1 & & 1 & 1 & & & & 1 & & 1 & \\
\hline 2010 & & & 2 & & 1 & 2 & & 1 & 3 & 1 & 1 & & 1 & 1 & \\
\hline
\end{tabular}




\begin{tabular}{|c|c|c|c|c|c|c|c|c|c|c|c|c|c|c|c|}
\hline 2011 & 1 & & 2 & & & 2 & & 1 & & 1 & & 1 & & & \\
\hline 2012 & & & 3 & & & 4 & & 2 & 2 & 1 & & 1 & 1 & 2 & 1 \\
\hline 2013 & & & 2 & & & 5 & 1 & 2 & & & & & & & \\
\hline 2014 & 2 & & & 2 & & 5 & & 2 & 1 & 3 & & 1 & & & \\
\hline 2015 & 4 & & 1 & & & 7 & & 6 & 2 & 2 & 1 & 1 & & & 1 \\
\hline 2016 & 2 & & 9 & 1 & 1 & 8 & 2 & 6 & 1 & 2 & & 2 & & & \\
\hline 2017 & 1 & & 4 & 5 & 3 & 7 & & 6 & 2 & & & 5 & 2 & 1 & \\
\hline 2018 & 1 & & 5 & 2 & 1 & 6 & 1 & 1 & 2 & 1 & & 4 & 1 & 3 & \\
\hline 2019 & 1 & 1 & 13 & 2 & 2 & 11 & & 15 & 2 & & & & & 1 & 3 \\
\hline 2020 & & & 3 & 1 & & 2 & & 4 & & & & 2 & & & \\
\hline Total & 16 & 2 & 58 & 14 & 11 & 70 & 8 & 56 & 19 & 12 & 2 & 21 & 6 & 9 & 6 \\
\hline
\end{tabular}

(TTS: Teacher training system, SPT: Selection of prospective teachers, PE: Program evaluation, CE: Course evaluation, PD: Program development, MD: Model development, AC: Academician competence, TC: Teacher competence, PTC: Prospective teacher competence, ACC: Accreditation, QS: Quality standards, LTP: Learning and teaching process, CEP: Comparison of education programs, PCK: Pedagogical content knowledge, PFE: Pedagogical formation education, TP: Teacher profile, TB: Teacher behavior, PTT: Prospective teacher training, ISTP: In-service training program, CFbT: Challenges faced by teachers.)

Table 6 shows that different subjects related to teacher education programs were studied in thesis studies done in the field of TEPs. Teacher competence/prospective teacher competence, program evaluation/course evaluation, and learning and teaching process were respectively the subjects mostly preferred. Considering the theses related to teacher competence / prospective teacher competence, it was determined that theses on the TEPs were generally done concerning professional competencies of teachers and/or prospective teachers, their attitudes, perceptions and readiness levels towards a subject or situation. In the theses related to program evaluation/course evaluation, it was found that programs belonging to the departments that train teachers in different fields or a course included in these programs (professional knowledge course, general knowledge course, and field knowledge course) were usually evaluated. One of the subjects that were frequently studied as related to the TEPs was learning and teaching process. Regarding the learning and teaching process, teacher education programs were generally studied in the theses in terms of the efficiency of method or techniques, micro education, in-class activities, learning styles, and technology.

Apart from these subjects, teacher profile/teacher behaviors, comparison of education programs, teacher training system, program development/model development, pedagogical content knowledge, academician competencies, in-service training program, accreditation/ quality standards, prospective teacher training, challenges faced by teachers, selection of prospective teachers, and pedagogical formation education were among the preferred subjects in the theses done on the TEPs. Based on this, it can be stated that teacher education programs were evaluated in the theses in relation to different subjects.

\section{Distribution of Theses According to Research Methods}

The distribution of the postgraduate theses completed in the field of TEPs according to research methods was presented in Table 7.

Table 7. Distribution of theses according to research methods

\begin{tabular}{|c|c|c|c|}
\hline \multirow{2}{*}{ Years } & \multicolumn{3}{|c|}{ Research Methods } \\
\hline & Quantitative & Qualitative & Mixed-Methods \\
\hline 1988 & & 1 & \\
\hline
\end{tabular}




\begin{tabular}{|c|c|c|c|}
\hline 1991 & 1 & & \\
\hline 1994 & 3 & & \\
\hline 1996 & 1 & & \\
\hline 1999 & 1 & & \\
\hline 2000 & 1 & & \\
\hline 2001 & 1 & 1 & \\
\hline 2002 & 1 & & \\
\hline 2003 & 1 & 2 & \\
\hline 2004 & 3 & 5 & \\
\hline 2005 & 1 & 2 & \\
\hline 2006 & 6 & 1 & \\
\hline 2007 & 4 & 2 & \\
\hline 2008 & 8 & 5 & 2 \\
\hline 2009 & 4 & 2 & 1 \\
\hline 2010 & 5 & 8 & \\
\hline 2011 & 3 & 4 & 1 \\
\hline 2012 & 6 & 8 & 3 \\
\hline 2013 & 4 & 2 & 4 \\
\hline 2014 & 5 & 8 & 3 \\
\hline 2015 & 9 & 13 & 3 \\
\hline 2016 & 14 & 16 & 4 \\
\hline 2017 & 14 & 8 & 14 \\
\hline 2018 & 8 & 9 & 11 \\
\hline 2019 & 19 & 25 & 7 \\
\hline 2020 & 2 & 3 & 7 \\
\hline Total & 125 & 125 & 60 \\
\hline
\end{tabular}

Table 7 shows that quantitative and qualitative research methods were used at equal rates in the postgraduate theses on the TEPs. In addition, the least preferred research method in these thesis studies was mixed-methods. The preference of mixed-methods research for teacher education programs was firstly seen in the theses conducted in 2008. As of the year 2008, mixed-methods were generally preferred in thesis studies and frequently used especially in 2017 and 2018.

\section{Distribution of Theses According to Research Designs}

The distribution of the postgraduate theses completed in the field of TEPs according to research designs was presented in Table 8 .

Table 8. Distribution of theses according to research designs

\begin{tabular}{|c|c|c|c|c|c|c|}
\hline \multirow{2}{*}{ Years } & \multicolumn{6}{|c|}{ Research Designs } \\
\hline & Survey & Case Study & Descriptive & Phenomenology & Experimental & Other \\
\hline
\end{tabular}




\begin{tabular}{|c|c|c|c|c|c|c|}
\hline 1988 & 1 & & & & & \\
\hline 1991 & & & & & & 1 \\
\hline 1994 & 1 & & 1 & & & 1 \\
\hline 1996 & & & & & 1 & \\
\hline 1999 & 1 & & & & & \\
\hline 2000 & & & 1 & & & \\
\hline 2001 & 1 & & 1 & & & \\
\hline 2002 & 1 & & & & & \\
\hline 2003 & 1 & & 1 & & 1 & \\
\hline 2004 & 2 & 3 & 3 & & & \\
\hline 2005 & & & 2 & & 1 & \\
\hline 2006 & 7 & & & & & \\
\hline 2007 & 3 & 2 & & & 1 & \\
\hline 2008 & 7 & 3 & & & 5 & \\
\hline 2009 & 4 & & 1 & & 2 & \\
\hline 2010 & 5 & 4 & 3 & 1 & & \\
\hline 2011 & 3 & 1 & 3 & 1 & & \\
\hline 2012 & 6 & 6 & 3 & 1 & 1 & \\
\hline 2013 & 3 & 2 & 2 & 2 & 1 & \\
\hline 2014 & 6 & 4 & 3 & 2 & 1 & \\
\hline 2015 & 7 & 8 & 4 & 5 & & 1 \\
\hline 2016 & 14 & 7 & 5 & 7 & 1 & \\
\hline 2017 & 9 & 8 & 6 & 3 & 10 & \\
\hline 2018 & 10 & 9 & 4 & 2 & 2 & 1 \\
\hline 2019 & 15 & 15 & 6 & 8 & 4 & 3 \\
\hline 2020 & 2 & 4 & 3 & & 3 & \\
\hline Total & 109 & 76 & 52 & 32 & 34 & 7 \\
\hline
\end{tabular}

Table 8 shows that research designs used in the thesis studies conducted on teacher education programs were survey, case study, descriptive, experimental, and phenomenology designs, respectively. In addition, some research designs that were preferred less in the postgraduate theses were included in the other category of the table. Action research ( 3 theses), exemplary case ( 2 theses), Delphi technique, and ethnography (1 thesis) were the research designs included in the other category.

The most preferred research designs in the theses completed on the TEPs are closely related to that quantitative and qualitative methods were equally used in the theses. Especially, the frequent use of survey research design in the theses is related to the fact that the mentioned research design can be carried out by both quantitative and qualitative methods. In addition, it can be stated that case study is generally preferred in qualitative methods and descriptive and experimental designs are usually preferred in quantitative methods.

\section{Distribution of Theses According to Samples}

The distribution of the postgraduate theses completed in the field of TEPs according to samples was presented in Table 9.

Table 9. Distribution of theses according to samples

\begin{tabular}{|c|c|c|c|c|c|c|c|}
\hline \multirow{2}{*}{ Years } & \multicolumn{7}{|c|}{ Samples } \\
\hline & Prospective Teacher & Teacher & Academician & Document & Student & Administrator & Other \\
\hline
\end{tabular}




\begin{tabular}{|c|c|c|c|c|c|c|c|}
\hline 1988 & & & 1 & 1 & & & \\
\hline 1991 & & 1 & 1 & & & 1 & 1 \\
\hline 1994 & 1 & 2 & 1 & & & & \\
\hline 1996 & 1 & & & & & & \\
\hline 1999 & & 1 & & & & & \\
\hline 2000 & 1 & & 1 & & & & \\
\hline 2001 & 1 & 1 & 1 & 1 & & & \\
\hline 2002 & 1 & 1 & & & & & \\
\hline 2003 & 1 & & & 2 & & & \\
\hline 2004 & 2 & 4 & & 3 & & & 1 \\
\hline 2005 & & 1 & 2 & 1 & & 1 & \\
\hline 2006 & 3 & 4 & 1 & 1 & & & \\
\hline 2007 & 5 & 3 & 1 & & & & \\
\hline 2008 & 9 & 3 & 1 & 7 & & & \\
\hline 2009 & 1 & 3 & 3 & 1 & 1 & & \\
\hline 2010 & 5 & 3 & 3 & 6 & 1 & 2 & \\
\hline 2011 & 5 & 4 & 2 & 1 & & & \\
\hline 2012 & 9 & 6 & 1 & 2 & & & \\
\hline 2013 & 9 & 2 & 2 & 1 & & & \\
\hline 2014 & 8 & 5 & 2 & 4 & 1 & & \\
\hline 2015 & 13 & 6 & 3 & 5 & 1 & 2 & \\
\hline 2016 & 23 & 9 & 9 & 5 & 1 & & 1 \\
\hline 2017 & 20 & 13 & 6 & 3 & 4 & & 2 \\
\hline 2018 & 15 & 9 & 8 & 5 & & & \\
\hline 2019 & 31 & 16 & 7 & 8 & 3 & 1 & 1 \\
\hline 2020 & 9 & 4 & 1 & 2 & & & 1 \\
\hline Total & 173 & 101 & 57 & 59 & 12 & 7 & 7 \\
\hline
\end{tabular}

Table 9 shows that the samples of the postgraduate thesis studies conducted on teacher education programs generally consisted of prospective teachers. In addition, teachers, documents, and academicians were also included in thesis studies, respectively. Although it was less when compared to the other samples, students (primary and secondary school students) and administrators (school principal-deputy principal, school inspector) were also included in the thesis studies. Prospective teacher ( 3 theses), graduate of the faculty of education ( 2 theses) and parent ( 2 theses) were in the sample given in the other category of the table.

When all the samples shown in the table are considered together, it is realized that the number of samples is higher than the number of theses analyzed in this study. This is related to the fact that more than one sample was usually included in the theses. It can be stated that different samples are simultaneously used in order to ensure the diversity of the data or to collect in-depth information in thesis studies.

\section{Distribution of Theses According to Data Collection Tools}

The distribution of the postgraduate theses completed in the field of TEPs according to data collection tools was presented in Table 10.

Table 10. Distribution of theses according to data collection tools

\begin{tabular}{|c|c|c|c|c|c|c|c|c|c|}
\hline \multirow[b]{2}{*}{ Years } & \multicolumn{9}{|c|}{ Data Collection Tools } \\
\hline & 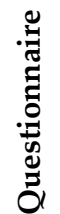 & ஸू & & 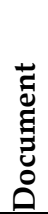 & 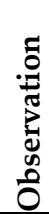 & 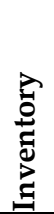 & $\stackrel{\vec{\phi}}{\Leftrightarrow}$ & $\stackrel{\overrightarrow{0}}{\overrightarrow{0}}$ & 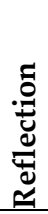 \\
\hline
\end{tabular}




\begin{tabular}{|c|c|c|c|c|c|c|c|c|c|}
\hline 1988 & & & 1 & 1 & & & & & \\
\hline 1991 & 1 & & & & & & & & \\
\hline 1994 & 2 & & & & 2 & & & & \\
\hline 1996 & 1 & 1 & & & & & & & \\
\hline 1999 & 1 & & & & & & & & \\
\hline 2000 & 1 & 1 & & & & & & & \\
\hline 2001 & 1 & & & 1 & & & & & \\
\hline 2002 & 1 & 1 & & & & & & & \\
\hline 2003 & & 1 & & 2 & & & & & \\
\hline 2004 & 3 & & 2 & 3 & & & & & 1 \\
\hline 2005 & 1 & & 1 & 1 & & & & & 1 \\
\hline 2006 & 2 & 3 & & 1 & & 2 & & & \\
\hline 2007 & 2 & 3 & 3 & & 1 & & & & \\
\hline 2008 & 5 & 3 & 3 & 7 & & 1 & 2 & 2 & \\
\hline 2009 & 4 & 2 & 2 & 1 & & 1 & & & \\
\hline 2010 & 3 & 2 & 6 & 6 & 3 & & 1 & & \\
\hline 2011 & 3 & 2 & 4 & 1 & 2 & & & & \\
\hline 2012 & 5 & 6 & 9 & 2 & 1 & 1 & & 2 & \\
\hline 2013 & 4 & 5 & 6 & 1 & 1 & & 2 & & \\
\hline 2014 & 2 & 4 & 8 & 4 & 4 & 1 & 2 & & \\
\hline 2015 & 7 & 6 & 12 & 5 & 7 & & 1 & & \\
\hline 2016 & 7 & 11 & 15 & 5 & 9 & 1 & & 1 & \\
\hline 2017 & 13 & 11 & 20 & 3 & 5 & 2 & 8 & 3 & \\
\hline 2018 & 7 & 14 & 17 & 5 & 3 & 1 & 1 & & \\
\hline 2019 & 12 & 13 & 25 & 8 & 6 & & 3 & 2 & \\
\hline 2020 & 4 & 6 & 9 & 2 & 1 & & & 1 & \\
\hline Total & 92 & 95 & 143 & 59 & 45 & 10 & 20 & 11 & 2 \\
\hline
\end{tabular}

Table 10 shows that the data collection tools mostly used in the process of collecting the data of the postgraduate theses done on the TEPs were interview, scale, questionnaire, document analysis, and observation forms, respectively. In addition, test, diary, inventory and reflection forms were also used as data collection tools in the theses. Interview forms used in the theses were mostly prepared by the researcher. On the other hand, scale forms to determine attitude, perception, competence, performance, thinking dispositions, belief, intelligence, and self-efficacy were often used in the scales in the theses. Personality, skill gain, literacy, and achievement test forms were widely used in the theses. In the inventory forms preferred in the theses, learning style and problem solving inventories were mostly used.

\section{Conclusion and Discussion}

A study in which theses on teacher education programs are evaluated together has not been found in the literature yet. Evaluating the completed scientific researches on teacher education programs together is important in order to show what research needs to be done on this subject. At the same time, it is possible to correlate and compare studies completed on teacher education programs with such studies that deal with many studies together. With this aspect, it is aimed that this research will contribute to new researches and researchers in terms of presenting holistic data about existing studies on teacher education programs.

310 theses were examined in this study in which the postgraduate theses completed in the field of teacher education programs. Firstly, it was determined in which universities and institutes the theses were conducted. Thus, the leading universities in respect to teacher education programs were determined. When the distribution of the theses according to universities was considered, it was found that the most theses in the field of the TEPs were completed in the METU. In addition, the leading universities in Turkey such as Gazi, 
Ankara and Hacettepe universities considerably included the postgraduate thesis studies in teacher education programs. 310 theses analyzed in the field of the TEPs were conducted in 49 universities. Concerning this, it can be stated that teacher education programs are regarded as one of the postgraduate research subjects in many universities in Turkey. When the distribution of the theses according to universities was examined by years, it was found that the number of theses in the field of the TEPs in universities increased especially as of 2008. This situation can be explained by the program change which was implemented in 2006-2007 academic year by the Council of Higher Education (CoHE, 2007). It is thought that the number of theses on teacher education programs increased as of the year 2008 in order to evaluate the amendments made in new programs and to compare these with the previous programs.

Institutes of educational sciences were at the forefront when considering in which institutes of these universities the theses in the field of the TEPs were done. The $52.9 \%$ of the postgraduate theses were completed in the institutes of educational sciences and $38.7 \%$ of the theses were completed in the institutes of social sciences. In addition, the institutes of science, health sciences, Ataturk's principles and history of Turkish revolution, forensic sciences, and postgraduate education also produced theses in teacher education programs. When it was compared to the universities at the forefront in the field of the TEPs, it was determined that universities which produced the most theses also had educational sciences or social sciences institutes. Based on this, it can be stated that the Institute of Social Studies of METU and the Institutes of Educational Sciences of Gazi, Hacettepe, and Ankara universities are appropriate for conducting more theses with the numbers of postgraduate programs, students, and instructors which they have (Ankara University Institute of Educational Sciences, 2020; Gazi University Institute of Educational Sciences, 2020; Hacettepe University Institute of Educational Sciences, 2020; Middle East Technical University Institute of Social Sciences, 2020). According to the 2019-2020 Academic Year Higher Education Statistics, the number of graduate students studying at the institutes is 2994 in Gazi Institute of Educational Sciences, 2298 in METU Social Sciences Institute, 1127 in Hacettepe Institute of Educational Sciences, 979 in Ankara Student Educational Sciences Institute. It was stated that the student was present (CoHE, 2021). When the distribution of the postgraduate theses according to departments was considered, it was found that teacher education programs were generally studied in the Department of Educational Sciences (23.2\%). In addition, theses on teacher education programs were often included in the departments of Primary/Basic Education, Curriculum and Instruction, English Language Teaching/English Language Instruction.

When the subjects that were studied in the postgraduate theses done in the field of the TEPs were examined, it was found that the subjects studied for teacher education programs in the theses were collected under 15 titles. These subjects were determined as teacher training system, selection of prospective teachers, program evaluation/course evaluation, program development/model development, academician competence, teacher competence/prospective teacher competence, accreditation/quality standards, learning and teaching process, comparison of education programs, pedagogical content knowledge, pedagogical formation education, teacher profile/teacher behaviors, prospective teacher training, in-service training program, and challenges faced by teachers. Among these subjects, the most theses on the TEPs were related to teacher competence/prospective teacher competence (22.6\%). Studies for determining professional competence, attitude, perception, and readiness levels were usually conducted in the theses handled in this title. For instance, theses on teacher education programs were carried out in different aspects such as English teachers' perception of competence, analysis of professional teaching competency, prospective chemistry teachers' attitudes towards teaching profession, prospective teachers' technology self-efficacy, and prospective teachers' perception on multicultural education. The other subject mostly studied in the field of the TEPs was program evaluation/course evaluation. When the theses on this subject were considered, it was found that evaluation studies were conducted in different programs or courses such as the evaluation of professional teaching knowledge courses, analysis of the teacher education programs, evaluation of teaching practice 
courses, evaluation of school experience courses, evaluation of classroom teaching undergraduate programs, evaluation of geography education, evaluation of preschool teacher training programs, and evaluation of gender education. This finding is similar to the results of the study conducted by Kozikoğlu and Senemoğlu (2015). In this study, the content analysis of dissertations completed in the field of Curriculum and Instruction was conducted and it was stated that the evaluation of formal education curricula and evaluation of teacher education curricula were among the mostly preferred topics in the dissertations (Kozikoğlu \& Senemoğlu, 2015).

When the findings related to the methods of the postgraduate theses analyzed in the field of the TEPs were examined, it was concluded that quantitative (40.3\%) and qualitative methods ( $40.3 \%)$ were equally used, but mixed-methods (19.4\%) was preferred less in the theses. Considering research designs with which these research methods preferred in the theses were used together, it was determined that survey $(35.2 \%)$, case study (24.5\%) and descriptive (16.8) designs were often preferred. Regarding this finding, Kurt and Erdoğan (2015) also stated that survey research design was mostly preferred in studies for program evaluation. In terms of the distribution of the theses done in the field of the TEPs according to the samples used, it was found that prospective teachers $(55.8 \%)$ were mostly included. In other words, more than half of the postgraduate theses in the field of teacher education programs included prospective teachers in their samples. It was also determined that teachers, documents, and academicians were often included in the samples of theses. On the other hand, the total number of the samples in theses was found higher than the number of theses analyzed. This finding shows that there were more than one sample group in the thesis studies done in the field of the TEPs. For instance, in some theses, while opinions of teachers and prospective teachers were obtained, document analysis was also used. In some other theses, data were collected from prospective teachers, teachers and academicians at the same time. It was found that the obtained findings were also supported by similar research results (Hazır Bıkmaz, Aksoy, Tatar \& Atak Altınyüzük, 2013; Kozikoğlu \& Senemoğlu, 2015; Kurt \& Erdoğan, 2015). Finally, when the findings about the data collection tools used in the theses completed in the field of the TEPs were evaluated, it was determined that interview, scale and questionnaire forms were mostly used in the theses. Scales for competence, self-efficacy, attitude, perception, performance, thinking dispositions, belief, and intelligence were frequently used especially in the theses done on teacher competence/prospective teacher competence. In addition, questionnaires were used in quantitative studies in order to determine teachers' and prospective teachers' opinions, and interview forms in qualitative studies.

In consideration of the findings obtained in this study in which the postgraduate theses completed in the field of the TEPs were analyzed, the subjects mainly studied in research conducted for teacher education programs were revealed. Based on the subjects studied in theses, it may be suggested to focus more on subjects such as in-service training programs, prospective teacher training, accreditation/quality standards, selection of prospective teachers, and academician competencies in new research to be done on teacher education programs. The repetition of similar subjects in the 310 theses examined in this study shows that there is a need for detailed research on these few subjects. It is understood that there is a need for comprehensive research on the accreditation of teacher education programs, quality studies in teacher education, and the pre-service, inservice and post-service development of teachers. The quality of teacher education programs is also related to the quality of teacher candidates and teaching staff. For this reason, the selection of teacher candidates and the competencies of teacher candidates should be revealed in new researches on teacher education programs. Similarly, there is a need for research on the qualifications of instructors in teacher education programs. Additionally, it is recommended that mixed-methods research be preferred more for future studies. Based on the results of the research, it is seen that studies on teacher education programs generally focus on samples consisting of teacher candidates. It may be advisable to include samples of field experts such as curriculum development, assessment and evaluation, educational sociology and educational psychology for teacher education programs in new researches. Incorporating the views of different stakeholders involved in the 
preparation, implementation and evaluation of teacher education programs will contribute to the development of teacher education programs.

A study in which theses on teacher education programs are evaluated together has not been found in the literature yet. Evaluating the completed scientific researches on teacher education programs together is important in order to show what research needs to be done on this subject. At the same time, it is possible to correlate and compare studies completed on teacher education programs with such studies that deal with many studies together. With this aspect, it is aimed that this research will contribute to new researches and researchers in terms of presenting holistic data about existing studies on teacher education programs. 


\section{REFERENCES}

Ankara University Institute of Educational Sciences. (2020). Retrieved from http://egitim.ankara.edu.tr/tarihce/

Büyüköztürk, Ş., Kılıç Çakmak, E. K., Akgün, Ö. E., Karadeniz, Ş. \& Demirel, F. (2012). Bilimsel araştırma yöntemleri $13^{\text {th }}$ ed.). Ankara: Pegem.

CoHE (1998). Eğitim fakültesi öğretmen yetiştirme lisans programları Retrieved from https://www.yok.gov.tr/Documents/Yayinlar/Yayinlarimiz/egitim-fakultesi-ogretmen-yetistirmelisans-programlari-mart-1998.pdf

CoHE (2007). Eğitim fakültesi öğretmen yetiştirme lisans programları. Retrieved from https://www.yok.gov.tr/Documents/Yayinlar/Yayinlarimiz/egitim-fakultesi-ogretmen-yetistirmelisans-programlari.pdf

CoHE (2018). Öğretmen yetiştirme lisans programları Retrieved from https://www.yok.gov.tr/Documents/Kurumsal/egitim_ogretim_dairesi/Yeni-Ogretmen-YetistirmeLisans-Programlari/AA_Sunus_\%20Onsoz_Uygulama_Yonergesi.pdf

CoHE (2020, January 4). YÖK'ten eğitim fakültelerinin müfredatlarına yönelik tarihi karar. Retrieved from https://www.yok.gov.tr/Sayfalar/Haberler/2020/egitim-fak\%C3\%BCltelerine-yetki-devri.aspx

CoHE (2021, April 10). 2019-2020 Öğretim Yllı Yükseköğretim İstatistikleri. Retrieved from https://istatistik.yok.gov.tr/

Creswell, J. W. (2017). Eğitim araştırmaları nicel ve nitel araştırmanın planlanması, yürütülmesi ve değerlendirilmesi (H. Ekşi, Trans. Ed.). Istanbul: EDAM.

Darling-Hammond, L. (2000). How teacher education matters. Journal of Teacher Education, 51(3), 166-173.

Darling-Hammond, L. (2006). Constructing 21st-century teacher education. Journal of teacher education, 57(3), 300-314.

Gazi University Institute of Educational Sciences. (2020, December 4). Retrieved from http://egtbil.gazi.edu.tr/posts/view/title/tarihcemiz-162597?siteUri=egtbil

Hacettepe University Institute of Educational Sciences. (2020, December 4). Retrieved from http://www.egitimbilimlerienstitusu.hacettepe.edu.tr/tr/menu/enstitunun_tarihcesi-4

Hazır Bıkmaz, F., Aksoy, E., Tatar, Ö. \& Atak Altınyüzük, C. (2013). The content analysis of PhD theses completed in the field of curriculum and instruction (1974-2009). Education and Science, 38(168), 288-303.

Kozikoğlu, İ \& Senemoğlu, N. (2015). Eğitim programları ve öğretim alanında yapılan doktora tezlerinin içerik analizi (2009-2014). Education and Science, 40(182), 29-41.

Kurt, A. \& Erdoğan, M. (2015). Program değerlendirme araştırmalarının içerik analizi ve eğilimleri; 2004-2013 y1lları arası. Education and Science, 40(178), 199-224.

Middle East Technical University Institute of Social Sciences. (2020, December 4). Retrieved from https://sbe.metu.edu.tr/tr/genel-bakis

Miles, M. B. \& Huberman, A. M. (2015). Nitel veri analizi (S. Akbaba Altun \& A. Ersoy, Çev. Ed.). Ankara: Pegem.

Sönmez, V. \& Alacapınar, F. G. (2013). Örneklendirilmiş bilimsel araştırma yöntemleri (2nd ed.). Ankara: Anı. 
Yıldırım, A. (2013). Teacher education research in Turkey: Trends, issues and priority areas. Education and Science, 38(169), 175-191.

Yıldırım, A. \& Şimşek, H. (2013). Sosyal bilimlerde nitel araştırma yöntemleri (9th ed.). Ankara: Seçkin.

Yılman, M. (2006). Türkiye'de öğretmen eğitiminin temelleri (2 ${ }^{\text {nd }}$ ed.). Ankara: Nobel.

Yüksel, S. (2011). Türk üniversitelerinde eğitim fakülteleri ve öğretmen yetiştirme (2 ${ }^{\text {nd }}$ ed.). Ankara: Pegem. 